\section{On melting icebergs}

HUPPERT AND TURNER'S laboratory studies $^{1}$ of ice melt in warm, salt-stratified water, which demonstrate a system of tilted convection layers of melt mixture interleaved with ambient fluid, are useful in focusing research upon the complex phenomenon of iceberg melt but can not be extrapolated so directly to in situ Antarctic iceberg melting as the authors have done, for several reasons: (1) density profile data corresponding to the $T, S$ profiles of the Weddell Sea station ${ }^{2}$ shown in Huppert and Turner's article are the depth ranges (and the corresponding density gradients) ${ }^{3}: \quad 30-50 \mathrm{~m} \quad(1.6 \times$ $\left.10^{-7} \mathrm{~g} \mathrm{~cm}^{-3} \mathrm{~cm}^{-1}\right) ; \quad 50-100 \mathrm{~m} \quad(1.5 \times$ $\left.10^{-8} \mathrm{~g} \mathrm{~cm}^{-3} \mathrm{~cm}^{-1}\right) ; \quad 100-300 \mathrm{~m} \quad(2 \times$ $\left.10^{-9} \mathrm{~g} \mathrm{~cm}^{-3} \mathrm{~cm}^{-1}\right)$; laboratory study ${ }^{1}(1-$ $\left.6 \times 10^{-3} \mathrm{~g} \mathrm{~cm}^{-3} \mathrm{~cm}^{-1}\right)$; as the mean density gradient has a major influence on the vertical scales of free convection it is difficult to see how laboratory results can describe the oceanic iceberg case where this parameter is from 10,000 to $1,000,000$ times smaller. In fact, the density difference over the typical $1 \mathrm{~cm}$ vertical scale of a single layer in the laboratory study is six times larger than the total difference in density from 30 $150 \mathrm{~m}$ of the Central Weddell Sea station. (2) At the $23^{\circ} \mathrm{C}$ temperature of Huppert and Turner's salt-stratified laboratory experiment, the thermal expansion coefficient is $0.17 \times 10^{-3} \mathrm{~g} \mathrm{~cm}^{-3} \mathrm{C}^{-1}$; in typical Antarctic waters it is $0.05 \times 10^{-3}$, less than one-third as effective in controlling density changes relative to the saline contraction factor which is much the same in both cases $\left(0.81 \times 10^{-3}\right.$ as opposed to $0.76 \times 10^{-3} \mathrm{~g} \mathrm{~cm}^{-3}$ p.p.t. ${ }^{-1}$, respectively). Furthermore, ambient water temperature in Antarctic water is only about $2{ }^{\circ} \mathrm{C}$ above freezing point, an order of magnitude different from their laboratory case. The overall thermal effect on density is then between one and two orders magnitude less in the Antarctic situation.

(3) Antarctic icebergs contain some 7\% by volume of compressed air ${ }^{4,5}$. Effects of air bubble release with melt water at depth are unknown but must be important in modifying vertical convection and horizontal heat diffusion across the boundary layer. A characteristic hissing sound has been reported near icebergs (Seelye Martin, personal communication).

(4) The tilted convection layers observed by Huppert and Turner occur at vertical increments of $1 \mathrm{~cm}$ and $2.5 \times$ $10^{-3} \mathrm{~g} \mathrm{~cm}^{-3}$ density difference. It required the available heat in $3.5 \mathrm{~g}$ ambient fluid to melt $1 \mathrm{~g}$ of ice; complete mixing would result in a mixture of density about $5.6 \times$ $10^{-3} \mathrm{~g} \mathrm{~cm}^{-3}$ less than that of the ambient fluid supplying the heat. The characteristic vertical scale of layers ought to have been $>2 \mathrm{~cm}$; it was not, which indicates that some melt heat was supplied by means other than turbulent diffusion, such as, double-diffusion. In the Antarctic iceberg case, for reasons (1-3), turbulent diffusion should dominate over other transfer mechanisms. While field measurements are lacking, data reported by Matthews and Quinlan ${ }^{6}$ for Muir Inlet, Alaska, showed that late winter modification of the bay water by glacier melt followed a $21: 1$ ratio. The ambient fluid at $3{ }^{\circ} \mathrm{C}$ and $31 \%$ salinity supplied about $96 \mathrm{cal} \mathrm{g}^{-1}$ of icemelt and part of this must have been needed to raise the ice temperature to melt point. Thus from the only available field data it seems that ice melt entrains ambient fluid with a ratio governed at a minimum by the heat available through complete mixing with ambient fluid, and not less as in the laboratory results ${ }^{1}$.

(5) Step structure observed in Central Weddell Sea profiles cannot be described as a plausible extension of the laboratory results. The thickest layer in the given profile extends from 100 to $200 \mathrm{~m}$ with a total density difference of $2 \times 10^{-5} \mathrm{~g} \mathrm{~cm}^{-3}$; a 1,250:1 mixing ratio is required to alter $1 \mathrm{~g}$ of melt water to ambient fluid density during its rise through this vertical distance, and the $2,250 \mathrm{cal}$ of available heat in the entrained fluid far exceeds that needed for melting.

A plausible extrapolation of the laboratory results of Huppert and Turner to the melting iceberg would state that the berg generates one such convective layer. A single cell convection was the basis of my earlier study ${ }^{3}$ on upwelling by icebergs. Even so, the existence of low horizontal temperature and vertical density gradients, compressed air bubbles in glacier ice and reduced thermal expansion effects, and velocity shear associated with berg motion severely limit the role of double-diffusion in iceberg melting (an exception might be the melting process of the bottom surface of the berg).

\section{S. NESHYBA}

School of Oceanography,

Oregon State University,

Corvallis, Oregon 97331

1. Huppert, H. E. \& Turner, J. S. Nature 271, 46-48 (1978). 2. Foster, T. D. \& Carmack, E. C. J. phys. Oceanogr. 6, 36-44 (1976)

3. Neshyba, S. Nature 267, 507-508 (1977)

4. Pounder, E. R. Physics of Ice (Pergamon, Oxford 1965).

5. Gow, A. W. Comm. Snow and Ice (Berkeley) (Int. Union Geod. and Geophy., publ. 61, 272, 1963).

6. Matthews, J. B. \& Quinlan, A. V. J. Fish. Res. Board Can. 32, 1693-1703 (1975).

\section{Kerogen maturation and petroleum generation}

UJIIÉ ${ }^{1}$ concluded that a one-point reversal in the C-H-O maturation pathway of kerogens of the Cretaceous of the Douala Basin indicated that a large amount of hydrocarbons was released from the kerogen. Other interpretations are possible. The basic problem is whether the anomaly reflects hydrocarbon release from similar kerogens, or indicates a change in the dominant kerogen type. The latter interpretation is appealing for three reasons.

(1) The anomalous point is not $(h)$ which lies directly on the projections of the maturation pathways defined by the shallower points $(a-f)$ and the deeper points $(i-n)$. The anomalous point is $(g)$ which has higher $\mathrm{C}$ and $\mathrm{H}$ and lower $\mathrm{O}$ contents than adjacent points. The kerogen at $(g)$ is near peak oil generation ${ }^{2}$. If the original kerogen types at $(f)$ and $(g)$ were essentially identical, the $\mathrm{H}$ content of the kerogen should be decreasing with depth, not increasing ${ }^{3}$. The increase in $\mathrm{H}$ content with depth from $(f)$ to $(g)$ indicates an increasing hydrocarbon generating capacity with depth, and suggests a corresponding change in original kerogen type.

(2) By themselves, the $\mathrm{C}-\mathrm{H}-\mathrm{O}$ relationships between points $(f, g, h)$ could be interpreted as primarily $\mathrm{CO}_{2}$ generation from $(f)$ to $(g)$ and hydrocarbon generation from $(g)$ to $(h)$. This explanation is unlikely. Pyrolysis experiments indicate that $\mathrm{CO}_{2}$ generation is greatly diminished by the time significant hydrocarbon generation begins ${ }^{4}$, as it has at $(f)$. In addition, thermogravimetric analyses of the $(f)$ and $(g)$ kerogens indicate that $(g)$ had a $50 \%$ greater weight loss at $500^{\circ} \mathrm{C}$ than $\operatorname{did}(f)^{5}$. If $(f)$ lost $\mathrm{CO}_{2}$ and reached the composition of $(g)$, the weight loss differential would be in the opposite direction.

(3) Kerogen is extracted organic matter. Its $\mathrm{C}-\mathrm{H}-\mathrm{O}$ contents should be identical at the same stage of thermal alteration whether the generated products remained in the kerogen in the subsurface or whether they were released in the subsurface. By itself, kerogen analysis yields no information on hydrocarbon release.

\section{R. W. JONES}

Chevron Oil Field Research Company,

La Habra, California 90631

1. Ujiié, Y. Nature 272,438-439 (1978).

2. Albrecht, P., Vanderbroucke, M. \& Mandenque, M. Geochim. cosmochim Acta 40, 791-799 (1976).

3. Laplante, R. E. Bull. Am. Ass. Petrol. Geol. 58, 1281-1289 (1974).

4. Espitalié, J. et al. Rev. Inst. Franc. Petrol 32, 23-42 (1977)

5. Durand, B. \& Espitalié, J. Geochim. cosmochim Acta 40 , 801-808 (1976). 